\title{
Probiotic Properties of Enterococcus faecium EF9296 Strain Isolated from Silage
}

\author{
M. MARCIŇÁKOVÁ, M. SIMONOVÁ, A. LAUKOVÁ \\ Institute of Animal Physiology Slovak Academy of Sciences, Košice, Slovakia \\ Received April 26, 2004 \\ Accepted October 26, 2004
}

\section{Abstract}

Marciňáková M., Lauková, A.: Probiotic Properties of Enterococcus faecium EF9296 Strain Isolated from Silage. Acta Vet. Brno 2004, 73: 513-519.

Ensilage means preserving forage fed by livestock when fresh material is less available. When the silo is opened, the silage is exposed to air and this leads to aerobic deterioration whereby aerobic microorganisms degrade lactic acid. Therefore, it is necessary to use some additives to control microbes in silage fermentation. The strain EF9296, isolate from silage was allotted to the species Enterococcus faecium by genotyping. This strain is sensitive to ampicillin $(10 \mu \mathrm{g})$, erythromycin $(15 \mu \mathrm{g})$, tetracycline, rifampicin, vancomycin $(30 \mu \mathrm{g})$ and it is kanamycin-resistant $(30 \mu \mathrm{g})$. EF9296 strain possess good adhesive capability to human as well as to canine mucus (human $5.5 \log 10 \mathrm{cfu} / \mathrm{ml}$, canine $4.7 \log 10 \mathrm{cfu} / \mathrm{ml}$ ). In addition, EF9296 is bile tolerant, lactic acid producing $(0.997 \pm 0.29 \mathrm{mmol} / \mathrm{l})$ with ureolytic activity $(16.9 \pm 1.2 \mathrm{nkat} / \mathrm{ml})$. The strain EF9296 produces a bacteriocin-like substance with the inhibitory activity against Gram-positive bacteria including enterococci and L. monocytogenes with activity from 100 to $800 \mathrm{AU} / \mathrm{ml}$. Amplified fragment of bacteriocin produced by 9296 strain corresponds with PCR signal for a structural gene of well-known enterocin A. Ent. faecium 9296 strain reached the stationary phase at $8 \mathrm{~h}$ in Trypticase-soy broth $(11.57 \pm 0.07 \log 10 \mathrm{cfu} / \mathrm{ml})$ and at $10 \mathrm{~h}$ in rumen fluid $(9.25 \pm 0.48 \log$ $10 \mathrm{cfu} / \mathrm{ml}$ ). It means, EF9296 strain grew in both media, although its growth in rumen fluid was slower in comparison with counts in TSY broth. In addition, the antilisterial effect of Enterococcus faecium EF9296 in rumen fluid was detected in experimental sample after $6 \mathrm{~h}$ from EF9296 strain application in comparison to the Listeria control sample $(0.4 \mathrm{log})$. This effect was prolonged up to the end of the experiment $(8 \mathrm{~h}-0.44 \log , 10 \mathrm{~h}-0.65 \log , 12 \mathrm{~h}-0.62 \mathrm{log})$. Enterococcus faecium EF9296 strain might be used as potential probiotic to protect silage against microbial contaminants e.g. Listeria spp.

Bacteria, silage, Listeria, Enterococci

Silage is the feedstuff produced by fermentation of forage crops of variable but often high moisture content. Ensilaging means to preserve forage (when abundant) for feeding livestock when fresh material is less available. In general, silage fermentation is a natural process whereby epiphytic lactic acid bacteria ferment water soluble carbohydrates in the crop to a number of products, primarily lactic acid, thereby reducing the $\mathrm{pH}$ as rapidly as possible, inhibiting spoilage microbes and preserving the maximum amount of nutrients in the product (Merry and Davies 1999). In Europe, an estimated 160 million tonnes of forage dry matter are ensiled annually (Wilkins on et al. 1996).

The ensilage process is divided into the initial aerobic phase, the fermentation phase and second aerobic phase when the silo is opened. The last phase has consequences for the quality of the product fed by livestock (Merry and Davies 1999). When the silo is opened and/or sealed inadequately, the silage is exposed to air. This may lead to aerobic deterioration. Aerobic microorganisms in silage degrade lactic acid and residual water-soluble carbohydrate to $\mathrm{CO}_{2}$ and protein and amino acids to amines, amides, and ammonia (Seale 1986). Aerobic deterioration generates considerable heat, increases $\mathrm{pH}$, and decreases digestibility (Woolford 1990). The main contaminants associated with aerobic spoilage activity in silage are yeasts, moulds, Bacillus spp. and Listeria spp. (McDonald et al. 1991). When lactic acid bacteria fail

Address for correspondence:

Miroslava Marciňáková

Institute of Animal Physiology

Slovak Academy of Sciences

Šoltésovej 4-6, 04001 Košice
Slovakia
Phone: +421-55-6330283

Fax: +421-55-7287842

E-mail: marcinak@ saske.sk
http://www.vfu.cz/acta-vet/actavet.htm 
to produce sufficient lactic acid during fermentation to reduce $\mathrm{pH}$ and inhibit the growth of butyric acid-producing bacteria, i.e. clostridia, the resulting silage will be of poor quality (McDonald et al. 1991). That is why to control silage microflora is important. There are many bacteria among lactic acid microorganisms, probiotic strains including, which are able to control the growth of undesirable flora in silage. Probiotics represent live microorganisms or microbial preparations or metabolites of stabilized autochtonous microorganisms which asses benefit effect on hosts organisms and affect microbial composition with stimulating effect on digestion and immunity of macro-organism (Nemcová 1997). Probiotic lactobacilli are also the most commonly species used as silage inoculants. However, among enterococci that belong to lactic acid bacteria (LAB) has been found bacteria with probiotic character too. It is believed that the inoculated populations of LAB genotypes become dominant in silage, thereby increasing the lactic acid concentration and decreasing $\mathrm{pH}$ values, gas, and protein decomposition (Inglis et al. 1999). Probiotic LAB are also fed by livestock to improve intestinal microbial balance, including elimination or reduction of undesirable microorganisms (Zhao et al. 1998). Viable microbial preparations, principally including lactic acid bacteria, have been proposed as a supplement in animal fodder (Cavazzoni and Adami 1991).

The use of silage for animal feeding has sometimes been associated with pathological problems, including listeriosis (Wiede mann et al. 1996). Because Listeria can grow at low temperatures (Tienungoon et al. 2000), hay crop silage stored in large plastic bags has frequently been contaminated (Wilkin son 1999).

The aim of this study was to characterize the strain of Enterococcus faecium EF9296 and to test it as potential silage probiotic (resulting from the selection criteria most typical of probiotics, i.e. adhesion ability of potential probiotic strain, antimicrobial activity, production of organic acid, tolerance to bile as well as from metabolic properties such as urease activity) to control, especially listerial contamination in silages.

\section{Materials and Methods}

Isolation and identification of the strain

Parallel samples of grass silages $(10 \mathrm{~g})$ were added into $90 \mathrm{ml}$ of saline solution $(0.85 \%$, $\mathrm{pH} 7)$ and vortexed. Then the samples were treated by the standard microbiological method; $100 \mu$ from the appropriate dilutions were plated onto M-Enterococcus agar (Becton \& Dickinson, Cockeysville, USA). Single colonies were picked up, checked for purity and used for genotypization. Genotypization of 9296 strain was provided by tDNA-PCR method after DNA extraction. For DNA preparation the strain was cultivated on Slanetz-Bartley agar (Oxoid, Basingstoke, Hampshire, England) at $37^{\circ} \mathrm{C}$ for $24 \mathrm{~h}$ and checked for purity. One bacterial colony was suspended in $20 \mu \mathrm{l}$ lysis buffer $(0.25 \%$ sodiumdodecylsulphate, $0.05 \mathrm{NaOH})$ and heated at $95^{\circ} \mathrm{C}$ for $5 \mathrm{~min}$. Lyzed cells were centrifuged briefly at $16000 \times \mathrm{g}$ to remove cell debris. Supernatant was used as template for tDNA-intergenic PCR (tRNAintergenic length polymorphism analysis, Baele et al. 2000) followed by capillary electrophoresis (Welsh and McClelland 1991). Following tRNA-gene consensus primers 5A(5'AGTCCGGTGCTCTAACCAACTGAG), T3B(5'AGGTCGCGGGTTGGAATCC) were used in order to amplify the intergenic regions between tRNA genes. The amplicons were separated by means of capillary electrophoresis using an ABI Prism 310 Genetic Analyser (Applied Biosystems, Foster City, CA, USA) at $60^{\circ} \mathrm{C}$ with a constant voltage of $1.5 \mathrm{kV}(10 \mathrm{~mA})$. The fragment lenghts were derived from the peak positions after intrapolation with the peak position of the size standard fragments. Electropherograms were interpreted visually and with a software program developed and described by Baele et al. (2000).

Intestinal mucus preparation and in vitro adhesion assay

Human intestinal mucus was isolated from the healthy part of resected colonic tissue as described Ouwehand et al. (2002). The use of human intestinal material was approved by the joint ethical commitee of the University of Turku and Turku University Central Hospital. Canine mucus was prepared according to Kirja vainen et al. (1998) and Ouwehand et al. (2002).

Adhesion to mucus was studied as described Ouwehand et al. (1999) using scintillation liquid. Results are expressed as the average of at least three independent experiments in four parallels (log 10 value of the number of bacteria adhered per microtitre plate).

Antimicrobial susceptibility testing

Antibiotic sensitivity or resistance was tested by agar disc diffusion method using Columbia agar (Becton \& Dickinson) enriched with $10 \%$ of defibrinated sheep blood. The following antibiotic discs (Becton \& Dickinson) 
were used: ampicillin $(10 \mu \mathrm{g})$, erythromycin $(15 \mu \mathrm{g})$, tetracycline, rifampicin, kanamycin, vancomycin and chloramphenicol $(30 \mu \mathrm{g})$. The strain was classified as resistant or sensitive according to the manufacturer's instructions. Ent. faecium CCM4231 was used as a positive control.

Testing of metabolic properties

To test tolerance of Enterococcus faecium EF9296 strain to bile, the strain was cultivated in Brain Heart broth enriched with $5 \%$ of oxgall (Becton \& Dickinson) at $37^{\circ} \mathrm{C}$ for $24 \mathrm{~h}$. The growth of strain was checked by measuring optical density (O.D. ${ }_{600}$ ) as well as by spreading of $100 \mu$ of cultures or appropriate dilutions onto Slanetz-Bartley agar (Oxoid, Basingstoke, Hampshire, England). Optical density and cells counts were compared with those after $24 \mathrm{~h}$. The growth of the strain was expressed in colony forming units per milliliter $(\mathrm{cfu} / \mathrm{ml}) \pm \mathrm{SD}$.

Production of lactic acid was measured by precipitate method according to Pryce (1969) and expressed in $\mathrm{mmol} / \mathrm{l}$ after four replicates $\pm \mathrm{SD}$

Urease activity was measured by the spectrophotometric method according to Cook (1976) and expressed in nkat $/ \mathrm{ml}$ after three replicates $\pm \mathrm{SD}$.

Bacteriocin production

Bacteriocin activity was detected by the agar spot technique according to De Vuyst et al. (1996) using Trypticasesoy agar as well as $0.7 \%$ Brian heart agar (Becton \& Dickinson) with overnight culture of indicator organism. Supernatant of potential producer $(10 \mu \mathrm{l})$ was spotted onto plates overlaid with $4 \mathrm{ml}$ of $0.7 \%$ agar containing $200 \mu \mathrm{l}$ of indicator organism. The plates were incubated at $37^{\circ} \mathrm{C}$ for $24 \mathrm{~h}$. Inhibitory activity was demonstrated by a clear zone around concentrated spots as well as diluted spots and expressed in arbitrary units per ml of culture medium (AU/ml). Arbitrary unit is defined as the reciprocal of the highest twofold dilution demonstrating complete inhibitory activity of the indicator strain.

Bacteriocin specification using PCR

The primer (5'- GGT ACC ACT CAT AGT GG AAA-3', 5'- CCC TGG AAT TGC TCC ACC TAA-3') and PCR reaction for bacteriocin-enterocin specification produced by Ent. faecium EF9296 strain was used according to A y merich et al. (1996). Total genomic DNA used as a template for PCR was isolated as is described in the part Isolation and identification of the strain. DNA from PCR reaction was separated by $2 \%$ agarose gel electrophoresis and gel was stained with $0.1 \mu \mathrm{g} / \mathrm{ml}$ of ethidium bromide and visualised by UV light. As positive control was used enterocin A produced by Enterococcus faecium EK13 (Mareková et al. 2003).

Growth of EF9296 strain in TSY broth and rumen fluid

The rumen fluid was taken from ruminaly fistulated sheep (Merino). In brief, the rumen fluid was centrifuged at $10000 \mathrm{~g}$ for $30 \mathrm{~min}$ and boiled to reach sterile fluid. Its "sterility" was checked on Columbia agar and TSY agar (Becton \& Dickinson) with $10 \%$ of sheep blood after overnight incubation at $37^{\circ} \mathrm{C}$

The EF9296 strain was cultivated in Trypticase-soy broth (Becton \& Dickinson) overnight at $37{ }^{\circ} \mathrm{C}$. Strain EF9296 (0.1\%) was added into TSY broth and rumen fluid. The samples were collected at $0 \mathrm{~h}, 2 \mathrm{~h}, 4 \mathrm{~h}, 6 \mathrm{~h}, 8 \mathrm{~h}$, $10 \mathrm{~h}, 12 \mathrm{~h}$ and $24 \mathrm{~h}$ after the inoculation. The growth of EF9296 strain was checked by using the plate counts of appropriate dilutions of the samples in saline solution $(0.85 \%, \mathrm{pH} 7)$ on Slanetz-Bartley agar (fy E.coli, Slovakia). The plates were checked for colonies after incubation at $37{ }^{\circ} \mathrm{C}$ for $24 \mathrm{~h}$ and the counts were expressed in log $10 \mathrm{cfu} / \mathrm{ml} \pm \mathrm{SD}$.

Competitive exclusion

Rumen fluid was divided into three equal volumes of $200 \mathrm{ml}$, which were used as the experimental sample (ES), EF9296 control sample (ECS) and Listeria control sample (LCS). Experimental sample was inoculated with $1 \%$ of overnight culture of Listeria innocua LMG 13568 strain (Universiteit Gent, Laboratorium voor Microbiologie, Belgium) and Enterococcus faecium EF9296 strain. Listeria control sample was inoculated with Listeria innocua LMG 13568. ECS was inoculated with Enterococcus faecium EF9296. Samples were cultivated by shaking in the water thermobath-incubator at $37^{\circ} \mathrm{C}$ for $24 \mathrm{~h}$ using $100-120 \mathrm{U} / \mathrm{min}$. The growth of strains and the inhibitory effect of Ent. faecium EF9296 strain against Listeria innocua LMG 13658 was checked during 24 h by spreading of 100 $\mu \mathrm{l}$ of the appropriate dilutions onto selective media. Listeria innocua LMG 13568 was counted on Oxford agar (Becton \& Dickinson) and the count of Ent. faecium EF9296 was determined using TSY agar (Becton \& Dickinson).

The mean differences $( \pm$ SD) are presented and expressed conventionally.

\section{Results}

The strain EF9296 was allotted to the species Enterococcus faecium. It possess good adhesive capability to human as well as to canine mucus (human $5.5 \log 10 \mathrm{cfu} / \mathrm{ml}$, canine $4.7 \log 10 \mathrm{cfu} / \mathrm{ml}$ ). Although EF9296 strain is sensitive to all selected antibiotics (ampicillin, vancomycin, rifampicin, tetracycline, chloramphenicol, erythromycin), this strain is kanamycin resistant. In addition, EF9296 is bile tolerant (growing even in the presence of $5 \%$ of oxgall), lactic acid producing $(0.997 \pm 0.29 \mathrm{mmol} / \mathrm{l})$ with ureolytic activity 
$(16.9 \pm 1.2 \mathrm{nkat} / \mathrm{ml})$. The strain produces a bacteriocin-like substance with the inhibitory activity against Gram-positive bacteria including enterococci (11 isolates from dog feed) with activity from 100 to $800 \mathrm{AU} / \mathrm{ml}$. Listeria monocytogenes CCM 4699 (Czech Collection of Microorganisms, Brno, Czech Republic) was inhibited by activity 400 AU/ml. Structural gene of well-known enterocin A was screened for using PCR and agarose gel electrophoresis revealed amplified fragment which corresponds with PCR signal for enterocin A.

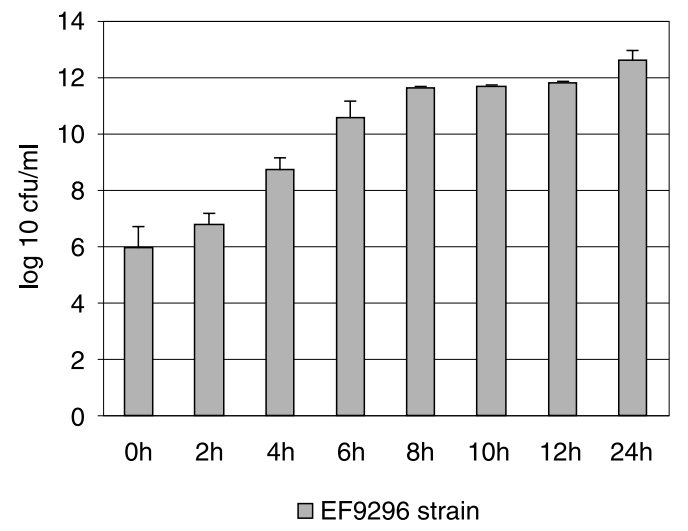

Fig. 1. Growth of Enterococcus feacium in TSY broth.

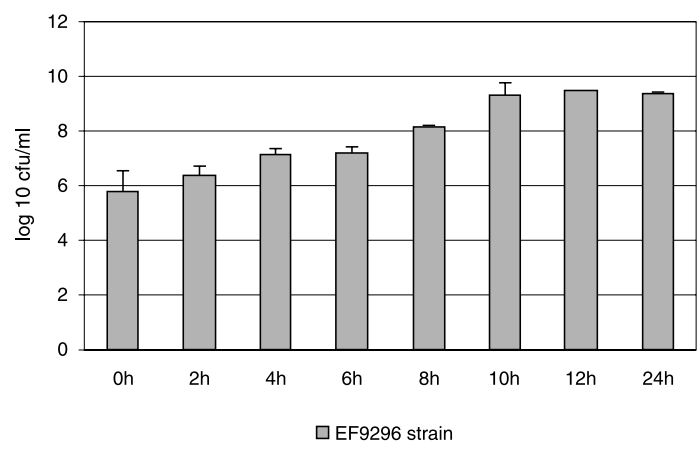

Fig. 2. Growth of Enterococcus feacium in rumen fluid.

Enterococcus faecium EF9296 grew very well in TSY broth (Becton \& Dickinson) as well as in the rumen fluid (Figs 1,2). At the start of cultivation $(0 \mathrm{~h})$ the counts of EF9296 strain reached $5.96 \pm 0.73 \log 10 \mathrm{cfu} / \mathrm{ml}$ in TSY broth and $5.75 \pm 0.75 \log 10 \mathrm{cfu} / \mathrm{ml}$ in rumen fluid. Stationary growth phase in TSY broth was reached after $8 \mathrm{~h}(11.57 \pm 0.07 \log 10 \mathrm{cfu} / \mathrm{ml})$. Stationary phase in rumen fluid was detected at $10 \mathrm{~h}(9.25 \pm 0.48 \log 10 \mathrm{cfu} / \mathrm{ml})$.

Slight inhibition of Listeria innocua LMG 13568 due to EF9296 strain with difference 0.4 $\log$ cycles was noted in ES after $6 \mathrm{~h}$ from EF9296 strain application in comparison to LCS. This effect was prolonged up to the end of the experiment (at $8 \mathrm{~h}$-differences $0.44 \mathrm{log}$ cycles, at $10 \mathrm{~h}-0.65 \log$ cycles, at $12 \mathrm{~h}-0.62 \mathrm{log}$ cycles, Fig. 3). Enterococcus faecium EF9296 grew very well in the rumen fluid with final count $9.17 \pm 0.03 \log 10 \mathrm{cfu} / \mathrm{ml}$ in ES and $10.12 \pm 0.82 \log 10 \mathrm{cfu} / \mathrm{ml}$ in ECS. 


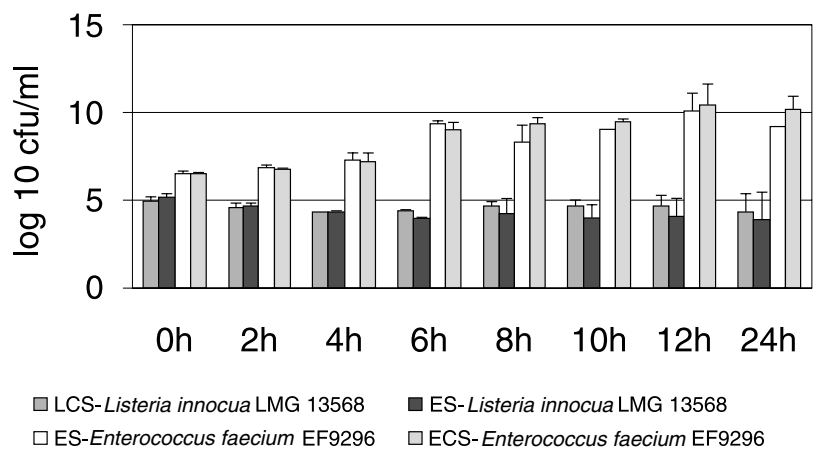

Fig. 3. Inhibition of Listeria innocua LMG 13568 due to Enterococcus faecium EF9296 in rumen fluid.

\section{Discussion}

The mechanism of effectiveness of a probiotic (although it is not fully clucidated) is closely associated with the properties of the production strains. Enterococcus feacium EF9296 used in this study is kanamycin resistant. Enterococci are intrinsically resistant against kanamycin (Franz et al. 1999). EF9296 strain binds to human intestinal mucus in a similar manner to that observed for canine mucus. This observation correlated with the adhesive capability of Lactobacillus sp. AD1 strain - potential canine probiotic (Strompfová et al. 2004). This suggests that often mentioned species specificity of probiotics is not interfering with the in vitro adhesion to intestinal mucus (Laukova et al. 2004). Tolerance to bile salts is considered to be a prerequisite for colonization and metabolic activity of bacteria in the small intestine of the host (Haven a ar et al. 1992). It is mentioned, that the resistance to bile salts varies a lot among the lactic acid bacteria species and even between strains themselves (Xanth opoulos 1997). EF9296 strain presented here as well as the other probiotic strain Lactobacillus sp. AD1 reported by Strompfova et al. (2004) were bile tolerant. The inhibitory components of probiotic strains comprise the production of bacteriocins or organic acid (e.g. lactic acid). EF9296 strain possess bacteriocin activity as well as it produces lactic acid; it can be supposed, that its inhibitory activity is due to actions of both substances. Enterocin A is a frequently detected bacteriocin among bacteriocin-producing enterococci originated from different sources e.g. environmental isolate Enterococcus faecium EK13, food isolate Ent. faecium CTC 492 (Mareková et al. 2003, Aymerich et al. 1996).

Enterococcus faecium EF9296 grew in both, in TSY broth as well as in the rumen fluid. Kalmok off et al. (1996) proposed the idea that lactic acid producing as well as bacteriocinproducing species; thus is, also enterococci, might be useful in silage fermentation. The addition of enterocin CCM 4231 to rumen fluid contaminated with Listeria monocytogenes OHIO strain (in early log phase) inhibited the growth of Listeria monocytogenes after $1 \mathrm{~h}$ of enterocin application by prolonged effect mainly at $24 \mathrm{~h}$ of cultivation (Lauková and Czikková 1998). Moreover, antilisterial effect of enterocin CCM 4231 was also reported for the other environments e.g. cattle slurry (Lauková et al. 1998). Addition of $200 \mathrm{AU} / \mathrm{ml}$ bacteriocin of Enterococcus faecium RZS C13 (isolate from silage) to a cell-suspension of Listeria monocytogenes resulted in an initial drop in number of viable cells (Vlaemynck et al. 1994). Slight inhibition of Listeria innocua LMG 13568 due to EF9296 strain in rumen fluid reported in this study confirmed antilisterial effect of enterococci and their bacteriocins previously refferred. In addition, the others bacteriocins of Enterococcus faecium e.g. enterocin A produced by Enterococcus faecium EK13 strain with probiotic character or 
enterocin M produced by Enterococcus faecium AL41 were active against Listeria innocua (Lauková and Mareková 2002; Lauková et al. 2003).

Although bacteriocin-producing bacteria are successfull in protection of silage against pathogens, Pauly et al. (1999) reported the effect of mechanical forage treatments on the growth of Listeria monocytogenes in grass silage. Precision chopping increased the concentration of lactic acid, reduced $\mathrm{pH}$ and counts of Listeria monocytogenes dropped on day 35 in the silage compared with unchopped grass.

It can be concluded, Enterococcus faecium EF9296 strain might be tested as potential probiotic and used to protect silage against microbial pathogens such as Listeria spp. However, additional experiments in silage ecosystem are required (e.g. adherence capability of the strain in silage, storing ability in silage, application and detection of enterocin production in silage, effect of lactic acid and enterocin in silage) and are in processing.

\section{Charakterizácia kmeňa Enterococcus faecium EF9296 - potenciálneho silážneho probiotika}

Silážovanie t.j. konzervovanie plodín v období, kedy je nedostatok čerstvých krmív, vhodných na kŕmenie hospodárskych zvierat je bežným biotechnologickým procesom $\mathrm{v}$ polnohospodárstve. Po otvorení sila za prístupu vzduchu dochádza k degradácii kyseliny mliečnej aeróbnymi mikroorganizmami. Kvôli týmto faktorom je potrebné používat silážne aditíva, ktoré by kontrolovali bakteriálny ekosystém počas fermentačnej fázy silážneho procesu. Kmeň EF9296 bol izolovaný zo siláže a genotypizovaný ako Enterococcus faecium. Tento kmeň je citlivý na ampicilin $(10 \mu \mathrm{g})$, erytromycin $(15 \mu \mathrm{g})$, tetracyklin, rifampicin a vankomycin $(30 \mu \mathrm{g})$, avšak je rezistentný na kanamycin $(30 \mu \mathrm{g})$. Adheruje rovnako dobre ako na ludskú, tak aj na psiu mukózu (ludská $5.5 \log 10 \mathrm{cfu} / \mathrm{ml}$, psia $4.7 \log 10 \mathrm{cfu} / \mathrm{ml})$. Okrem toho je kmeň EF9296 rezistentný na žlčové soli, produkuje kyselinu mliečnu $(0.997 \pm 0.29 \mathrm{mmol} / \mathrm{l})$ a je ureolytický $(16.9 \pm 1.2 \mathrm{nkat} / \mathrm{ml})$. Kmeň EF9296 dosiahol stacionárnu fázu po 8. hodinách rastu v Tryptikáza-sójovom bujóne (Becton \& Dickinson; $(11.57 \pm 0.07 \log 10 \mathrm{cfu} / \mathrm{ml})$ a po 10 . hodinách rastu v bachorovej tekutine $(9.25 \pm 0.48 \log 10 \mathrm{cfu} / \mathrm{ml})$. Kmeň Enterococcus faecium EF9296 zredukoval počty listérií v experimentálnej vzorke bachorovej tekutiny po 6 hodinách od podania kmeňa EF9296 pri porovnaní s kontrolnou vzorkou, ktorá obsahovala len listérie (rozdiel $0.4 \log$ cyklu). Tento efekt pretrvával až do konca experimentu ( $8 \mathrm{~h}-0.44 \mathrm{log}$ cyklu, $10 \mathrm{~h}-0.65 \log$ cyklu, $12 \mathrm{~h}-0.62 \mathrm{log}$ cyklu). Kmeň Enterococcus faecium EF9296 predstavuje potenciálne silážne aditívum, avšak dalšie testovania in vitro ako aj in vivo sú nevyhnutné.

\section{Acknowledgements}

This study was supported by the project VEGA 2/2043/24 of Slovak Scientific Agency. The excellent technical assistance of Margita Bodnárová is gratefully acknowledged. Genotyping of EF9296 strain was provided during study stay of Dr. Lauková at University of Ghent in Laboratory of Dr. Luc Devriese.

\section{References}

AYMERICH, T, HOLO, H, HAVARSTEIN, LS, HUGAS, M, GARRIGA, M, NES, IF 2003: Biochemical and genetic characterization of enterocin A from Enterococcus faecium, a new antilisterial bacteriocin in the pediocin family of bacteriocins. Appl Environ Microbiol 62: 1676-1682

BAELE, M, BAELE, P, VANEECHOUTTE, M, STORMS, V, BUTAYE, P, DEVRIESE, L, VERSCHRAEGEN, G, GILLIS, M, HAESEBROUCK, F 2000: Application of tDNA-PCR for the identification of enterococci. J Clin Microbiol 38: 4201-4207

CAVAZZONI, V, ADAMI, A 1991: Premesse sperimentali per l'utilizzazione come probiotico di un batterio sporigeno di nuovo isolamento. Atti Convegno,,Agrobiotechnologie nei processi di valorizzazione dei prodotti agricoli“. C.N.R.-R.A.I.S.A. (4.1.4) Volterra: 113

COOK, AR 1976: Urease activity in the rumen of sheep and the isolation of ureolytic bacteria. J Gen Microbiol 92 : $32-48$ 
DE VUYST, L, CALLEWAERT, R, PO, B 1996: Characterization and antagonistic activity of Lactobacillus amylovorus DCE471 and large scale isolation of its bacteriocin amylovorin L471. System Appl Microbiol 19: 269-277

FRANZ, C, HOLZAPFEL, WH, STILES, ME 1999: Enterococci at the crossroads of food safety ? Int J Food Microbiol 47: 1-24

HAVENAAR, R, TEN BRINK, B, HUIS IN'T VELD, JHJ 1992: Selection of strains for probiotic use. In: Probiotics - the Scientific Basis. ed. Fuller, R, Chapman and Hall, London, pp: 209-221

INGLIS, GD, YANKE, LJ, KAWCHUK, LM, MCALLISTER, TA 1999: The influence of bacterial inoculants on the microbial ecology of aerobic spoilage of barley silage. Can J Microbiol 45: 77-87

KALMOKOFF, ML, BARTLETT, F, TEATHER, RM 1996: Are ruminal bacteria armed with bacteriocins? J Dairy Sci 79: 2297-2308

KIRJAVAINEN, PV, OUWEHAND, AC, ISOLAURI, E, SALMINEN, S, 1998: The ability of probiotic bacteria to bind to human intestinal mucus. FEMS Microbiol Lett 167: 185-189

LAUKOVÁ, A, CZIKKOVÁ, S, VASILKOVÁ, Z, JURIŠ, P, KRUPICER, I 1998: Antimicrobial effect of enterocin CCM 4231 in the cattle slurry environment. Cytobios 94: 73-79

LAUKOVÁ, A, CZIKKOVÁ, S 1998: Inhibition effect of enterocin CCM 4231 in the rumen fluid environment. Letters Appl Microbiol 26: 215-218

LAUKOVÁ, A, MAREKOVÁ, M 2002: A bacteriocin-mediated antagonism by Enterococcus faecium EK13 against Listeria innocua in tofu. Arch Lebensmittel 53: 25-48

LAUKOVÁ, A, TUREK, P, MAREKOVÁ, M, NAGY, J 2003: Use of ent M, new variant of ent P to control Listeria innocua in experimentally contaminated Gombasek sausage. Archiv fur Lebensmittelhygiene 54: $25-48$

LAUKOVÁ, A, STROMPFOVÁ, V, OUWEHAND, AC 2004: adhesion properties of enterococci to intestinal mucus of different hosts. Vet Res Commun 28: 1-9

MAREKOVÁ, M, LAUKOVÁ, A, DE VUYST, L, SKAUGEN, M, NES, I F 2003: Partial characterization of bacteriocins produced by environmental strain Enterococcus faecium EK13. J Appl Microbiol 94: 523-530

MCDONALD, P, HENDERSON, N, HERON, S 1991: The Biochemistry of Silage. 2nd Ed Aberystwyth, UK: Chalcombe Publications: 48-249

MERRY, R J, DAVIES, D R 1999: Propionibacteria and their role in the biological control of aerobic spoilage in silage. Lait 79: 149-164

NEMCOVÁ, R 1997: Criteria of selection of lactobacilli for probiotic use. Vet Med Czech 42: 19-27

OUWEHAND, AC, SALMINEN, S, TOLKKO, S, ROBERTS, P, OVASKA, J, SALMINEN, E 2002: Resected human colonic tissue: new model for characterizing adhesion on lactic acid bacteria. Clin Diag Lab Immunol 9: 184-186

PAULY, TM, HANSSON, IB, THAM, WA 1999: The effect of mechanical forage tratments on the growth of Clostridium tyrobutyricum and Listeria monocytogenes in grass silage. Anim Feed Sci Technol 78: 127-139

PRYCE, JD 1969: A modification of the barker-Summerson method for the determination of lactic acid. Analyst 94: $1151-1152$

SEALE, DR 1986: Bacterial inoculants as silage additives. J Appl Bacteriol Symp Suppl 9: S-26S

STROMPFOVÁ, V, LAUKOVÁ, A, OUWEHAND, AC 2004: Lactobacilli and Enterococci - Potential Probiotocs for Dogs. Folia microbiol 49: 203-207

TIENUNGOON, S, RATKOWSKY, DA, McMEEKIN, TA, ROSS, T 2000: Growth limits of Listeria monocytogenes as a function of temperature, $\mathrm{pH}, \mathrm{NaCl}$, and lactic acid. Appl Environ Microbiol 66: 4979-4987

VLAEMYNCK, G, HERMAN, L, COUDIJZER, K 1994: Isolation and characterization of two bacteriocins by Enterococcus faecium strains inhibitory to Listeria monocytogenes. Food Microbiol 24: 211-225

WELSH, J and McCLELLAND, M 1991: Genomic fingerprints produced by PCR with consensus tRNA gene primers. Nuc Acid Res 19: 861-866

WIEDEMANN, M, BRUCE, JL, KNORR, R, BODIS, M, COLE, EM, MCDOWELL, CL, McDONOUGH, PL, BATT, CA 1996: Ribotype diversity of Listeria monocytogenes strains associated with outbreaks of listeriosis in ruminants. J Clin Microbiol 34: 1086-1090

WILKINSON, J M, WADEPHUL, F, HILL, J 1996: A Survey of 33 Countries. Lincoln, Chalcombe Publication WILKINSON, J M 1999: Silage and animal health. Nat Toxins 7: 221-232

WOOLFORD, M K 1990: A review: The detrimental effects of air on silage. J Appl Bacteriol 68: 101

XANTHOPOULOS, V, LITOPOULOU-TZANETAKI, E, TZANETAKIS, N 1997: In vitro study of lactobacillus species strains on bile tolerance and cholesterol removal. In: Lactic Acid Bacteria - Lactic 97. Caen: Presses universitaires de Caen

ZHAO, T, DOYLE, M P, HARMON, B G, BROWN, C A, MUELLER, P O 1998: Reduction of carriage of enterohemorrhagic Escherichia coli O157:H7 in cattle by inoculation with probiotic bacteria. J Clin Microbiol 36: $641-647$ 